\title{
FLOOD MAGNITUDE AND FREQUENCY OF MONONGAHELA BROOK AT THE CULVERT ON NEW JERSEY ROUTE 41, DEPTFORD TOWNSHIP, GLOUCESTER COUNTY, NEW JERSEY
}

U.S. GEOLOGICAL SURVEY

Open-File Report 96-320

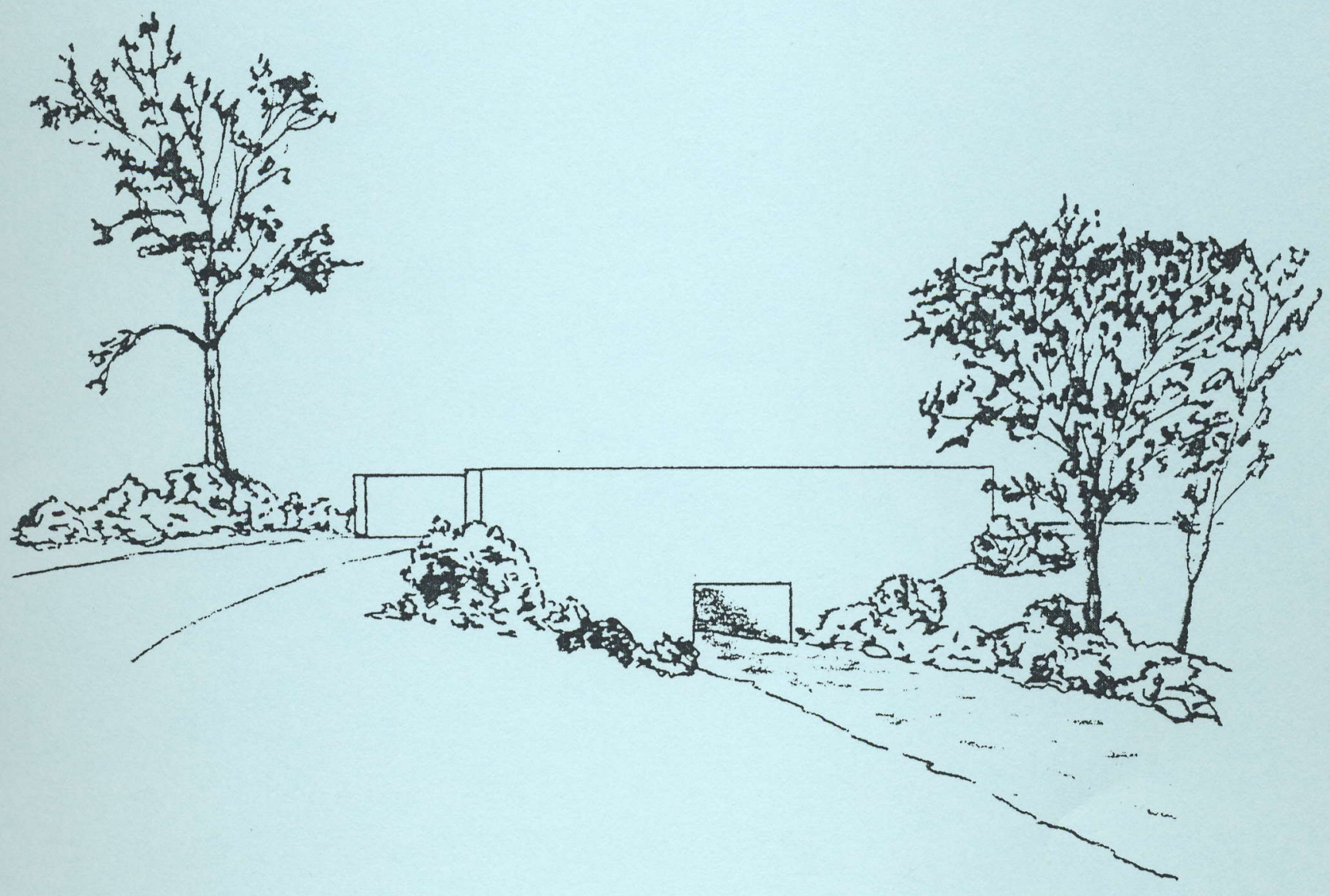

Prepared in cooperation with the NEW JERSEY DEPARTMENT OF TRANSPORTATION

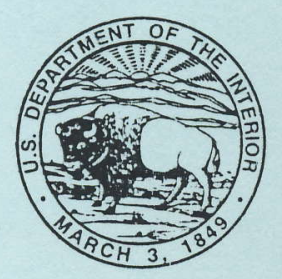




\section{FLOOD MAGNITUDE AND FREQUENCY OF MONONGAHELA BROOK AT THE CULVERT ON NEW JERSEY ROUTE 41, DEPTFORD TOWNSHIP, GLOUCESTER COUNTY, NEW JERSEY}

By Thomas Barringer

U.S. GEOLOGICAL SURVEY

Open-File Report 96-320

Prepared in cooperation with the

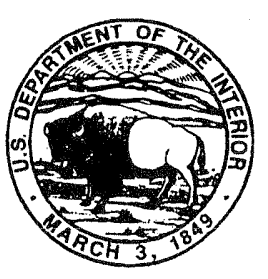
NEW JERSEY DEPARTMENT OF TRANSPORTATION

West Trenton, New Jersey 1996 


\section{U.S. DEPARTMENT OF THE INTERIOR}

BRUCE BABBITT, Secretary

\section{U.S. GEOLOGICAL SURVEY}

Gordon P. Eaton, Director

For additional information

write to:

District Chief

U.S Geological Survey

Mountain View Office Park

810 Bear Tavern Road, Suite 206

West Trenton, NJ 08628
Copies of this report can be obtained from:

U.S Geological Survey

Earth Science Information Center

Open-File Reports Section

Box 25286, MS 517

Denver Federal Center

Denver, CO 80225 


\section{CONTENTS}

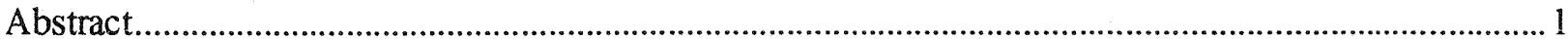

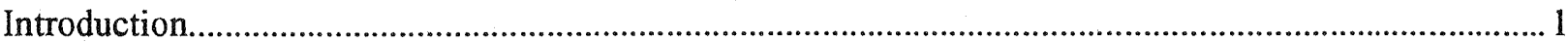

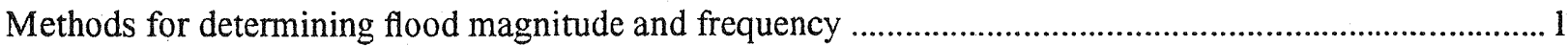

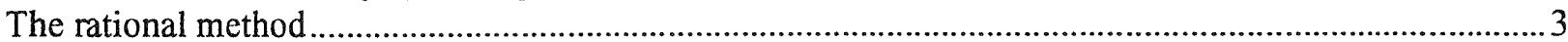

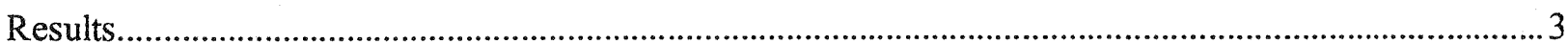

Selected references

\section{ILLUSTRATIONS}

Figure 1. Map showing location of Monongahela Brook at the culvert at milepost 0.9 on New Jersey

Route 41 and associated drainage basin, Deptford Township, New Jersey

\section{TABLES}

Table 1. Explanatory variables for the flood-magnitude and -frequency analysis of Monongahela Brook at the culvert on New Jersey Route 41, Deptford Township, New Jersey 4

2. Flood-magnitude estimates for selected flood frequencies using the rational method, Monongahela Brook at the culvert on New Jersey Route 41, Deptford Township,

New Jersey 


\section{CONVERSION FACTORS}

Multiply

foot (ft)

mile (mi)

square mile $\left(\mathrm{mi}^{2}\right)$

foot per mile ( $\mathrm{ft} / \mathrm{mi}$ )

cubic foot per second $\left(\mathrm{ft}^{3} / \mathrm{s}\right)$
By

0.3048

1.609

2.590

0.189

0.0283
To obtain

meter

kilometer

square kilometer

meter per kilometer

cubic meter per second 


\title{
FLOOD MAGNITUDE AND FREQUENCY OF MONONGAHELA BROOK AT THE CULVERT ON NEW JERSEY ROUTE 41, DEPTFORD TOWNSHIP, GLOUCESTER COUNTY, NEW JERSEY
}

\author{
By Thomas Barringer
}

\begin{abstract}
Flood magnitude and frequency of Monongahela Brook in Deptford Township, Gloucester County, New Jersey, were determined by using the rational method. Flood-magnitude and -frequency estimates, as well as drainage-basin characteristics, are included in this report. The 100 -year-flood estimate is 80 cubic feet per second.
\end{abstract}

\section{INTRODUCTION}

Information on the magnitude and frequency of floods is critical to the planning and design of highway culverts and bridges. Such information is not readily available for many stream crossings in New Jersey. To fulfill this information need, the U.S. Geological Survey, in cooperation with the New Jersey Department of Transportation, began an analysis of flood data from stream-crossing sites on New Jersey streams.

This report presents results of the analysis for the culvert at milepost 0.9 of New Jersey Route 41 in Deptford Township, New Jersey. The culvert is located about midway between Fairview and Blackwood Terrace, New Jersey (fig. 1). The drainage area upstream from the site is $0.072 \mathrm{mi}^{2}$. A field reconnaissance was performed on February 23, 1995, to verify the locations of the drainage-basin divides and basin characteristics. Because the direction of storm-sewer drainage in some parts of the basin are uncertain, the calculated drainage area is approximate.

The flood-insurance study for Deptford Township (Federal Emergency Management Agency, 1982), in which the subject basin lies, does not include a detailed study of this stream; therefore, flood discharges were not determined previously.

\section{METHODS FOR DETERMINING FLOOD MAGNITUDE AND FREQUENCY}

Various widely used methods for calculating flood magnitude and frequency were considered for use in determining the flood magnitudes that are likely to be exceeded at this site within a given number of years (recurrence interval). The rational method (Chow and others, 1988), New Jersey Department of Environmental Protection (NJDEP) Special Report 38 method (SR 38) (Stankowski, 1974), the U.S. Soil Conservation Service (SCS) Technical Release 55 (TR-55) method (U.S. Soil Conservation Service, 1986), the U.S. Geological Survey (USGS) transfer method (NJDEP, 1988), and the index-flood method (Thomas, 1964) were all considered for use in determining flood magnitude and frequency at the subject culvert.

Flood data from three streamflow gages located in basins with characteristics similar to those of the subject basin and within a 23-mi radius of the culvert site were examined to determine whether the rational method provides reasonable estimates of flood magnitude. These data were used to compute the USGS transfer-method estimates. Flood magnitude and frequency computed by using the rational method were compared with estimates made by using the USGS transfer method, the NJDEP SR 38 method, and the TR-55 method. 

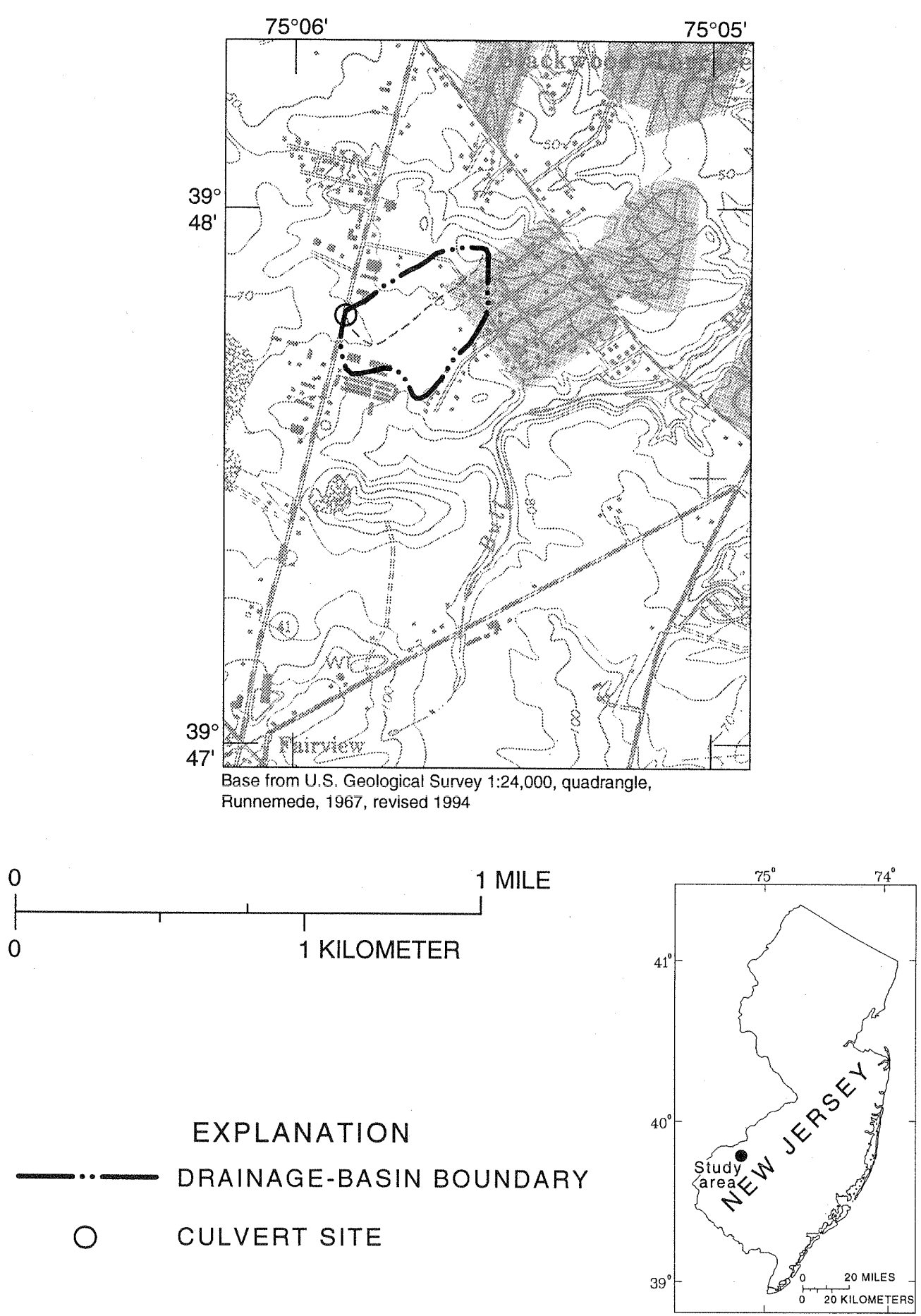

Figure 1. Location of Monongahela Brook at the culvert at milepost 0.9 on New Jersey Route 41 and associated drainage basin, Deptford Township, New Jersey. 


\section{THE RATIONAL METHOD}

The rational method is recommended for estimating peak discharges at ungaged sites located in uniform drainage areas of not more than $0.5 \mathrm{mi}^{2}$ (Chow and others 1988). The estimates of the 100-year flood made for the New Jersey Route Route 41 site by using the SR 38 method and the TR-55 method were 0.8 and 1.1 times, respectively, the estimates obtained by using the rational method. Estimates of the 100 year flood at the subject site made by using the USGS transfer method were $0.5,1.04$, and 1.1 times that of the rational method estimate using flood data from three stations (Newton Creek at Collingswood, New Jersey, 01467305; South Branch Newton Creek at Haddon Heights, New Jersey, 01467317; and West Branch Cohansey River at Seeley, New Jersey, 01412500). The rational method estimate was chosen because of its close general agreement with the transfer method estimates.

\section{RESULTS}

Flood data from nearby streamflow- or crest-stage gaging stations provide a good indication of the flood magnitude and frequency that can be expected at an ungaged site, particularly when drainage area and other basin characteristics are similar. In this study, estimates obtained by using the rational method were compared with estimates made using the USGS transfer method. In addition, the rational method estimates were compared with estimates made by using the SR 38 and TR-55 methods. For the subject site, all estimates compared well with one another, the rational method estimate was near the median of the set of estimates.

Explanatory variables used in applying the rational method are listed in table 1 . The floodmagnitude and -frequency estimates obtained by using the rational method are shown in table 2 . The estimate of the 100-year flood discharge at the culvert site is $80 \mathrm{ft}^{3} / \mathrm{s}$. 
Table 1. Explanatory variables for the flood-magnitude and -frequency analysis of Monongahela Brook at the culvert on New Jersey Route 41, Deptford Township, New Jersey

Drainage area: 0.072 square miles

Latitude: $39^{\circ} 47^{\prime} 47^{\prime \prime}$

Longitude: $75^{\circ} 05^{\prime} 53^{\prime \prime}$

Highway: New Jersey Route 41

Milepost: 0.9

U.S. Geological Survey 7-1/2-minute quadrangle: Runnemede, N.J.

\begin{tabular}{llll}
\hline \multicolumn{1}{c}{ Variable } & & Value & Unit \\
\hline Drainage area & $=$ & 0.072 & square miles \\
Rational method runoff coefficient & $=$ & 0.61 & \\
2-year, 24-hour rainfall intensity & $=$ & 1.31 & inches per hour \\
5-year, 24-hour rainfall intensity & $=$ & 1.68 & inches per hour \\
10-year, 24-hour rainfall intensity & $=$ & 1.94 & inches per hour \\
25-year, 24-hour rainfall intensity & $=$ & 2.26 & inches per hour \\
50-year, 24-hour rainfall intensity & $=$ & 2.54 & inches per hour \\
100-year, 24-hour rainfall intensity & $=$ & 2.84 & inches per hour \\
\hline
\end{tabular}

${ }^{1}$ From New Jersey Department of Environmental Protection, 1988.

${ }^{2}$ All rainfall intensity values from Frederick and others, 1977. 
Table 2. Flood-magnitude estimates for selected frequencies using the rational method, Monongahela Brook at the culvert on New Jersey Route 41, Deptford Township, New Jersey

$[Q$, flood-magnitude estimates in cubic feet per second along with number indicating frequency of recurrence interval, in years]

Drainage area: 0.072 square miles

Latitude: $39^{\circ} 47^{\prime} 47^{\prime \prime}$

Longitude: $75^{\circ} 05^{\prime} 53^{\prime \prime}$

Highway: New Jersey Route 41

Milepost: 0.9

U.S. Geological Survey 7-1/2-minute quadrangle: Runnemede, N.J.

\begin{tabular}{lcccccc}
\hline Estimating method & Q2 & Q5 & Q10 & Q25 & Q50 & Q100 \\
\hline Rational method & 37 & 47 & 55 & 64 & 71 & 80 \\
\hline
\end{tabular}




\section{SELECTED REFERENCES}

Chow, V.T., Maidment, D.R., and Mays, L.W., 1988, Applied hydrology: New York, McGraw-Hill, 572 p.

Federal Emergency Management Agency, 1982, Flood insurance study of Deptford Township, Gloucester County, New Jersey: Federal Emergency Management Agency, May 17, 1982, 18 p., 14 pls., 8 panels.

Frederick, R.H., Myers, V.A., and Auciello, E.P., 1977, Five- to 60-minute precipitation frequency for the eastern and central United States: National Oceanic and Atmospheric Administration Technical Memorandum NWS HYDRO-35, Silver Spring, Md., June 1977, 36 p.

New Jersey Department of Environmental Protection, 1988, Technical manual for stream encroachment: New Jersey Department of Environmental Protection, Division of Water Resources, Bureau of Floodplain Management, 151 p., 6 app.

Stankowski, S.J., 1974, Magnitude and frequency of floods in New Jersey with effects of urbanization: New Jersey Department of Environmental Protection, Special Report 38, 46 p.

Thomas, D.M., 1964, Floods in New Jersey, magnitude and frequency: New Jersey Department of Conservation and Economic Development, Water Resources Circular 13, 145 p.

U.S. Soil Conservation Service, 1986, Urban hydrology for small watersheds: Engineering Division Technical Release 55, Washington, D.C., 162 p. 